\title{
Information and analytical support for the development of teacher education in Russia
}

\author{
Igor Pavlov ${ }^{1}$,Emmanuil Bagramyan ${ }^{1}$,Elena Sakharchuk ${ }^{1 *}$, and Elena Volya $^{1}$ \\ ${ }^{1}$ Russian Academy of Education, 119121, Moscow, Russian Federation
}

\begin{abstract}
The relevance of the study is due to the need to implement the Russian national system of teachers' professional growth, in the context of strategic priorities (reflected in the national projects "Education" and "Science"), as well as in the context of a new pedagogical reality: digitalization, integration into professional pedagogical education of practical knowledge, change of teachers' generations, etc. The aim of the study was to develop scientific ideas about the structure and principles of analytical support for updating lifelong education (its structure, content and process). The initial materials of the research were as follows: educational standards and programs in pedagogy (levels of secondary and higher professional education); research materials from leading Russian scientific schools in the field of pedagogical education, etc. The results of the study clearly shown the existing significant backlog of scientific-theoretical and scientific-applied research corresponded with the answers to the main challenges which the system of professional pedagogical education faces nowadays. At the same time, the need was revealed to consolidate the efforts of research teams, as well as the generation of scientific ideas in order to solve problems by the compositions of interregional expert groups. To solve the problem of consolidation, the organization of expert and analytical activities in teacher education has been developed, and its following main components have been identified: network management of expert and analytical activities, coordination of experts on problematic issues in teacher education and its key issues, and development of expert infrastructure.
\end{abstract}

\section{Introduction}

The introduction of a national system for the professional growth of teachers as an achievement of the practical use of innovative concepts in the field of teacher education determines the content of the requirements for the information and analytical base - an integrated scientific, information and expert and analytical basis for the construction and functioning of the system of training teachers in the context of the strategic objectives of its development [1].

The innovative development of Russian pedagogical education at the present stage is associated with the solution of such urgent tasks as: support of the continuous education

\footnotetext{
* Corresponding author: e.sakharchuk2013@yandex.ru
} 
system [2], interdisciplinary and inter-level integration of its psychological support [3], digitalization and informatization in the educational process [4], development of research and project activities [5].

The strategic benchmark for the future development and reconstruction of teacher education, in accordance with modern concepts, is defined as the formation of its integrity based on conceptual generalization and adoption of the model of "key goals of the teacher's professional activity" $[6,7]$.

The relevance of the study is due to the need to form general ideas about the content and possibilities of coordinating the processes of scientific information and expert analytical support of measures for the implementation of practical mechanisms of program documents, primarily the federal project "Teacher of the Future" national project "Education".

Analytical generalizations based on the systematization of the latest achievements of the psychological and pedagogical sciences clearly indicated the existing significant backlog of scientific-theoretical and scientific-applied research in the mainstream of answers to the main modern challenges. At the same time, there is a demand for the integrative consolidation of the efforts of research teams, as well as the generation of scientific ideas for solving problems: the implementation of models of lifelong education (education throughout life); preparing a "person for education"; the growth of the importance of the activity component and project activity in education; development needs of the "knowledge producer"; a combination of diversification and standardization of educational activities; integration of subject areas; as well as problems of an organizational, managerial and structurally meaningful nature in solving urgent problems of sustainable development of pedagogical education, providing training and professional growth of teachers $[8,9,10]$.

\section{Literature review}

Studies currently underway in the world indicate the growing influence of politics on education [11], the strengthening of the connection between society and education [12], the interdisciplinarity of sciences and the openness of pedagogy to impulses from outside: politics, administration, society [13].

Modern research differentiates itself along two main lines: with an emphasis on students and the teacher, with an emphasis on the subject and content [14]. At the same time, the idea of the science of education as a metadiscipline has been formed [15].

This study is based on the results of major international studies reflecting scientific interests and preferred methods in the educational sciences of scientists, mainly from the post-socialist space [16]. The importance of international studies is increasing in connection with the processes: unification of values [17]; rethinking the values of education [18]; rethinking the concept of "responsibility" in education [19].

As the analysis of numerous sources shows, an idea of the mutual influence of society and the education system is currently formed [20], at the same time, the mechanisms for improving educational policy in a particular country are not clearly represented, taking into account the available scientific achievements, including when improving the content of education, taking into account national strategic interests or adaptation of foreign experience.

\section{Methodology}

The leading methodological vector of the research is the anthropological approach, which allows integrating ideas about the three main components of the pedagogical education 
system: content, structural-institutional and process. To study the problems of analytical support for each of the components, the following source materials were used: federal laws and regulations, texts of national projects (Education, Science), federal state educational standards, basic professional educational program. To study the expert assessment, the scientific interests of the leading Russian scientific and pedagogical schools (primarily represented by the scientific centers of the Russian Academy of Education) were analyzed. We also conducted an expert of: 1) the current regulatory requirements for the content of education contained in Federal Law N 273-FZ "On Education in the Russian Federation", Federal State Educational Standards of Higher and Secondary Professional Education for the enlarged group of areas of training "Education and Pedagogical Sciences "; 2) data on the content and regulations of procedures for establishing compliance of the educational content with regulatory requirements in terms of the description of assessment tools and source materials. The conclusion was made that the existing information and analytical support for management decisions does not correspond to the needs of teacher education.

\section{Results}

The revealed lack of functioning of the pedagogical education has as one of the consequences the problem of systemic management and the associated asynchronous nature of managerial actions to regulate the content of training and development of pedagogical personnel. In particular, the main tasks of improving information and analytical support of teacher education in order to determine the degree of compliance of its content with regulatory requirements include the tasks related to:

- the clarification of subjects, functions, subject area and content of analytical activities in the system of external independent assessment of the quality of education;

- the development of the sectoral qualifications framework, revision of professional standards and the development of federal state requirements for education in the field of pedagogy;

- development of tools for assessing the compliance of the results of pedagogical education with the needs of individuals or legal entities in whose interests educational activities are carried out;

- the development of tools for assessing the compliance of the content of educational programs with the requirement of the unity of the educational space, and others.

\section{Conclusions}

As a direction for solving the identified problems of a theoretical and regulatory nature, it is proposed to consider information and analytical support for the development of teacher education in Russia as an activity on:

- facilitating decision-making in the development and implementation of state educational policy, strategic directions, goals and programs for the development of education, interaction with state authorities and local authorities;

- identification of mechanisms for the preservation and stabilization of the teaching profession; the formation of the most complete picture of the current state and development trends of the pedagogical education system of the Russian Federation; development of conditions for increasing the efficiency of professional and pedagogical communities;

- preparation of proposals aimed at developing the material and social base of the psychological and pedagogical sciences, etc.

The following principles of information and analytical support for the development of pedagogical education have been substantiated: 
- purposefulness: focus on achieving specific goals and solving tasks;

- consistency: maintaining performance and a comprehensive analysis of issues to be solved, taking into account their place, role and relationships in the general structure of the pedagogical education system;

- relevance: compliance with the needs of practical activity in the system of teacher education;

- timeliness: presentation of results in the right time frame, in a convenient form to interested parties;

- activity: determining the dynamics of the development of the situation under study and anticipating possible negative consequences, establishing and explaining the patterns of change in indicators;

- initiative: defining and describing issues, formulating tasks and proposing solutions;

- reliability: taking into account the truthfulness of the initial analysis data, the accuracy of the quantitative data used;

- objectivity: the absence of bias, the analyst's impartial attitude to research and its results;

- completeness: the use of all available information necessary to solve the assigned tasks, etc.

The expert approach determined by us as the dominant organizational and methodological vector for the implementation of assessment procedures that provide the necessary level of information and analytical support for managerial decision-making for the sustainable development of the training system and professional development of teaching staff.

The structure of the organization of expert and analytical activity has been determined and its following main components have been identified:

- network management,

- coordination of experts on problematic issues of teacher education and key issues of its development,

- expert infrastructure (both within institutions and departments, and in coordination with each other, the Russian and foreign professional and expert community).

The expert-analytical activity in the post-nonclassical period is characterized by the following parameters:

- the inclusion of axiological factors in the explanatory provisions;

- methodological pluralism;

- consideration of synergistic aspects;

- naturalness of uncertainty, scholasticity, nonlinearity and bifurcations; convergence of methods of natural and social sciences;

- using the apparatus of hermeneutics, methods of social and humanitarian expertise; systematic approach to object research.

The following main directions of expert activity in teacher education have been determined:

- using the potential of intellectual resources as an information and expert environment;

- using the potential of intellectual resources for deep analytical study of the most complex problems;

- authoritative support: using the personal authority of the most famous representatives of the expert community when organizing support for the designed solutions and measures for their implementation.

The subjects and sources of data from the expert environment are potentially:

- scientific communities in the field of teacher education, functioning at departments or public organizations; 
- communities of organizations and their subdivisions (scientific academies, institutes, centers, laboratories), whose functions are the production of knowledge in the field of teacher education;

- communities of editorial boards and authors of top-rated journals in relevant scientific specialties;

- expert discussion platforms;

- Russian, international and foreign databases with the necessary qualimetric ranking tools. For each group, current lists of subjects are presented. The directions of informationanalytical and expert support of pedagogical education at the level of organizations carrying out educational activities are systematized.

The contribution of the team of authors to the solution of the identified problems is the development of conditions, principles of construction, goals, objectives, content, functions and forms of organizing expert and analytical activities in the field of pedagogical education in the context of applying a modern eco-pragmatic approach.

This view allows us to view every knowledge, action, or idea from a practical point of view or expediency. It can be used for the sustainable development of the training system and professional development of teaching staff.

The scientific results obtained by the team of authors create the basis for further research and make it possible to develop ideas about the formation on the basis of the Russian Academy of Education of a single scientific and applied ecosystem of information and analytical support for the development of pedagogical education.

\section{References}

1. Pedagogical education in modern Russia: strategic development guidelines: monograph, scientific editor Yu.P. Zinchenko, Publishing House of the Southern Federal University (2020)

2. V.S. Lazarev, Key problems of modernization of pedagogical education, Pedagogical education and science, No. 4 (2017)

3. E.V. Galazhinsky, V.I. Kabrin, Prospects for the development of the creative personality of the transfessional in the context of the change in the scientific and educational paradigm of the university, Bulletin of the Tomsk State University. No. 447 (2019)

4. I.V. Robert, Directions of development of informatization of domestic education in the period of digital information technologies, Electronic libraries, T.23. No. 1-2 (2020)

5. N.D. Podufalov, On the strategy of RAO in the context of modern challenges to the education system, Professional and higher education: challenges and development prospects: a collective monograph (2020)

6. M.V. Boguslavsky, T.N. Boguslavskaya, K.Yu. Milovanov, A.V. Ovchinnikov, Cultural and historical foundations of the development of national education and pedagogy in the second half of the XX - early XXI centuries, Problems of modern education, No. 3 (2020)

7. Emmanuil Bagramyan*, Elena Sakharchuk and Elena Volya, Pedagogical excellence in the focus of research at Russian universities, SHS Web of Conf., Volume 87 (2020)

8. S.Yu. Egorov, R.S. Shilko, A.I.Kovalev, Prospects for the development of digital education: analysis from the standpoint of the system-activity approach, Bulletin of the RFBR, No.4 (104) (2019) 
9. E.S. Sakharchuk, Implementation of federal state educational standards of higher education in the context of the requirements of professional standards: socio-cultural aspect, Vestnik MGUKI, No 1(87) (2019)

10. A.V. Lubkov, Modern problems of pedagogical education, Education and Science, Volume 22, No. 3 (2020)

11. J. Bellmann, H. Su, Democracy and Bildung/Erziehung: Towards a universal theory of education. Education Science 7(5): 1-11 (2017)

12. E. Grimaldi, What future for educational research in Europe? Political, epistemological and ethical challenges. European Educational Research Journal, 14(1): 49-55 (2015)

13. E. Terhart, Interdisciplinary research on education and its disciplines: Processes of change and lines of conflict in unstable academic expert cultures - Germany as an example. European Educational Research Journal, 16(6): 921-936 (2017)

14. M. Elken, S. Wollscheid, The relationship between research and education: Typologies and indicators - A literature review. Report 2016: 8, Oslo: Nordic Institute for Studies in Innovation, Research and Education (NIFU). Available at: https://brage.bibsys.no/xmlui/bitstream/id/418864/NIFUreport2016-8.pdf (accessed 10 December 2020)

15. M. Kalantzis, B. Cope, New Learning: Elements of Science of Education. Second edition. Melbourne: Cambridge University Press (2012)

16. Characteristics of educational sciences research activity in European post-socialist countries in the period 1996 to 2013: Content analysis approach. Articlein European Educational Research Journal. February 2019. DOI: 10.1177/1474904119827462 (2019)

17. M. Lawn, Transnational lives in European educational research. European Educational Research Journal 13(4) : 481-492 (2014)

18. F. Antunes, Economising education: From the silent revolution to rethinking education. A new moment of Europeanisation of education? European Educational Research Journal 15(4): 410-427 (2016)

19. A. Collins, R. Halverson, Rethinking education in the age of technology: the digital revolution and the school (2009) Available at: https://llk.media.mit.edu/courses/readings/Collins-Rethinking-Education.pdf (accessed 10 December 2020)

20. E.S. Sakharchuk, Russian professional education in the international context: methodological problems of the research. Bulletin of the MSRU. Series: Pedagogics, No 4, P.161-173 (2018). 